\title{
PEMIDANAAN KEBIRI TERHADAP PELAKU KEJAHATAN SEKSUAL KEPADA ANAK PERSPEKTIF HAK ASASI MANUSIA DAN HUKUM ISLAM
}

\author{
1Ahmad Jamaludin, 2Sayid Mohammad Rifqi Noval \\ 1,2Fakultas Hukum Universitas Islam Nusantara \\ E-mail: jamaludinumam@gmail.com, Juristdomain@gmail.com
}

\begin{abstract}
Sexual crimes in Indonesia have become increasingly worrying, especially against children, efforts to protect child victims by the government with Perpu No.1 of 2016 which has been passed into Law Number 17 of 2017 concerning child protection. This Perpu provides for additional regulations with castration for sexual crimes against children. The making of this policy was tinged with pros and cons because it was not in accordance with the objectives of punishment and Islamic law. The research method used is normative juridical with quantitative analysis. The purpose of this research is to see the view of the purpose of the punishment of chemical castration which is released to perpetrators of sexual crimes and to see and explain the Islamic legal views of the act of castration. The results of this study are First, the implementation of castration is an act of violence and contrary to the 1945 Constitution, namely Article 28 G paragraph 2 and Article 33 paragraph 1 of Law No. 39 of 1999 concerning Human Rights. Both Islamic Laws do not speak in writing about castration. The castration penalty stipulated in Law 17 of 2016 is a prohibition which is categorized as a punishment for takzir, because it is made by the state or leaders to overcome sexual crimes against children. The conclusion of this research is that first, castration punishment is a punishment that can violate human rights. Second, castration punishment in Islam is categorized as takzir punishment.
\end{abstract}

Keywords: Chemical Castration; Conviction; Human Rights

\begin{abstract}
Abstrak
Kejahatan seksual di Indonesia sudah semakin menghawatirkan tertutama terhadap anak, upaya perlindungan kepada anak korban skesual dilakukan pemerintah dengan Perpu Nomor 1 tahun 2016 yang telah disahkan menjadi UU Nomor 17 tahun 2017 tentang perlindungan anak. dalam Perpu ini diatur mengenai sanksi tambahan dengan tindakan kebiri untuk pelaku kejahatan seksual kepada anak. Pembuatan kebijakan tersebut diwarnai prokontra karena dianggap tidak sesuai dengan Tujuan
\end{abstract}


Pemidanaan dan Hukum Islam. Metode Penelitian yang digunakan adalah yuridis normative dengan analisis kuantitatif, Tujuan dari peneliitian ini adalah untuk mengetahui pandangan tujuan pemidanaan terhadap hukuman kebiri kimia yang dijatuhkan kepada Pelaku Kejahatan seksual dan untuk mengetahui serta menjelaskan pandangan hukum islam terhadap hukuman tindakan kebiri. Hasil dari penelitian ini adalah Pertama, Pelaksanaan tindakan kebiri merupkan sebuah tindakan bentuknya tindakan kekerasan dan bertentangan dengan UUD 1945 yaitu pada Pasal 28 G ayat 2 dan Pasal 33 ayat 1 Undang-undang No 39 Tahun 1999 tentang Hak asasi Manusia. Kedua Hukum islam tidak mengatur secara tegas mengenai hukuman kebiri. Hukuman kebiri yang diatur dalam UU 17 tahun 2016 merupakan hukuman yang dikatagorikan sebagai hukuman takzir, sebab sibuat oleh negara atau pemimpin untuk menanggulangi kajahatan seksual terhadap anak. Kesimpulan dari penelitian ini adalah Pertama Hukuman Kebiri adalah Hukuman yang dapat melanggar Hak Asasi Manusia, Kedua Hukuman kebiri dalam Islam dikatagorikan sebagai Hukuman Takzir.

Kata-kata Kunci: Kebiri Kimia; Pemidanaan; Hak Asasi Manusia

\section{Pendahuluan}

Anak merupakan amanah serta karunia Tuhan Yang Maha Esa, yang dalam dirinya juga melekat harkat dan martabat sebagai manusia seutuhnya yang tidak dapat dicederai. Mereka merupakan harapan bangsa, penerus cita-cita dan memiliki peran strategis dalam menjamin keberlangsungan eksistensi bangsa dimasa yang akan datang. Negara memberikan hak dasar yang termaktub dalam konstitusi kita tepatnya dalam pasal 28 B ayat (2) UUD 1945, bahwa negara menjamin setiap anak berhak atas kelangsungan hidup, tumbuh dan berkembang serta berhak atas perlindungan dari kekerasan dan diskriminasi.

Kejahatan seksual terhadap anak merupakan kejahatan yang serius dan merupakan pelanggaran Hak Asasi Manusia. Berdasarkan data dari Komisi Perlindungan Anak Indonesia (KPAI) Anak sebagai korban kejahatan seksual cenderung mengalami kepningkatan. Tahun 2016, 2017, 2018 dan 2019 angka kejatan seksual terhadap anak secara berturut-turut antara lain 192 kasus, 188 kasus, 182 kasus dan 162 kasus.

Fenomena kekerasan seksual yang cenderung meningkat ini menunjukan Indonesia masih banyaknya serta tingginya angka kekerasan dan kejahatan seksual terhadap anak. anak yang diharapkan meneruskan perjuangan bangsa dan negara harus menelan pil pahit menjadi korban 
kekerasan pelaku kejahatan seksual, sehingga memberikan perlindungan bagi anak merupakan merupakan kewajiban dan suatu hal yang realistis. Bagi anak, perlindungan adalah sebuah hak yang harus mereka terima dari negara dan wajib menjungjung tinggi haknyaitu terutama harkat martabat anak itu sendiri. Kekerasan seksual kepada anak berbeda dengan kasus lainnya, kasus kekerasan ini akan membawa dampak yang serius baik langsung maupun dalam jangka waktu yang sangat Panjang, selain itu juga akan meningglkan luka secara fisik, psikis serta mempengaruhi perkembangan emosional anak tersebut yang menjadi korba kekerasan seksual. ${ }^{1}$

Merespon fenomena kekerasan seksual terhadap anak yang semakin meningkat, untuk menekan angka kejahatan seksual pemerintah mengeluarkan kebijakan berupa Perpu nomor 1 Tahun 2016 yang sudah disahkan menjadi Undang-undang No. 17 tahun 2016 tentang perlindungan anak. Perpu tersebut secara subtansial mengatur hukuman tambahan berupa kebiri dengan rehabilitasi.

Kebiri adalah tindakan untuk menurunkan/menghilangkan hasrat seksual dan libido pada seseorang yang telah melakukan kejahatan seksual. Cara yang dilakukan pada kebiri kimia adalah dengan menyuntikan obat berupa senyawa kimia kedalam tubuh, obat tersebut akan berfungsi mengurangi testoteron dan estradiol, hormone seksual pada pria. Kebiri kimia merupakan bentuk hukuman tambahan yang dijatuhkan kepada pelaku kejahatan seksual diatur dengan dalam pasal 81 ayat 7 dengan kriteria pelaku adalah residivis kejahatan seksual, korbannya lebih dari satu orang, adanya luka berat, gangguan jiwa, penyakit menular, terganggu dan atau hilangnya fungsi reproduksi atau sampai meninggal dunia.

Hukuaman kebiri kimia merupakan bentuk hukuman yang terbilang baru, hal tersebut tidak diatur dalam macam-macam hukuman sebagaimana pasal 10 Kitab Undang-Undang Hukum Pidana (KUHP), seialin itu muncul reakasi masyarakat yang menyatakan setuju dan ketidaksetujuan terhadap aturan tersebut. Sebab disatu sisi hukuman kebiri mampu menekan angka kejahatan seksual terhadap anak, membuat efek jera serta mencegah pelaku semakin banyak, akan tetapi disisi

1 Nur Hafizal Hasanah and Eko Suponyono, "Kebijakan Hukum Pidana Sanksi Kebiri Kimia Dalam Perspektif HAM Dan Hukum Pidana," Jurnal Megister Hukum Udayana 7, no. 3 (2018): 305-317. 
lain hukuman kebiri dianggap sebuah tindakan yang melanggar Hak Asasi Manusia (HAM). Hak asasi adalah hak yang paling dasar yang harus dimiliki oleh semua manusia sebagai anugrah dari tuhan, kapanpun dan dimanapun harus menjungung harkat martabat manusia. Kaitannya dengan hukuman kebiri, Konstitusi kita jelas mengatur bahwa negara tidak boleh menghukum masyarakatnya dengan merendahkan harkat martabat manusia sebagai hak dasar manusia, sehingga human kebiri dianggap sebuah hukuman yang terdapat tindakan kekerasan dan dianggap bertentangan dengan UUD 1945 yakni hak untuk tidak dilakukan penyiksaan dan hak untuk bebas dari perlakuan yang merendahkan harkat martabat serta derajat manusia. Hukuman kebiri tersebut bertentangan dengan pasal 28 G (2) UUD 1945 serta pasal 33 (1) Undangundang Nomor 39 tahun 1999 tentang Hak Asasi Manusia selain itu Indonesia telah meratifikasi konvensi anti penyikdaan dan perlakuan hukuman yang kejam, tidak manusiawi dan merendahkan harkat martabat manusia melalui Undang-undang No. 5 tahun 1998.

Pro kontra hukuman kebiri juga terjadi pada Lembaga Negara seperti Komisi Nasional Hak Asasi Manusia (Komnas Ham) dan Ikatan Dokter Indonesia sebagai organisasi resmi dokter di Indonesia. Komnas Ham berpendapat dalam konferensi persnya pada tanggal 15 februari 2015 menyatakan bahwa hukuman kebiri telah melanggar hak asasi manusia, terlebih Indonesia sudah meratifikasi konvensi antipenyiksaan, sehingga hukuman kebiri harus dibatalkan. Sejalan dengan Komnas Ham, Ikatan Dokter Indonesia juga menolak namun meraka menolak menjadi eksekutor hukuman kebiri, IDI berpendapat bahwa dokter tidak dapat melakukan eksekusi kebiri karena bertentangan dengan sumpah, etika dan disiplin kedokteran yang berlaku internasional selain itu menurut IDI hukuman kebiri tidak menjamin hilang atau berkurangnya hasrat dan potensi pelaku untuk mengulangi perbuatannya akan hilang.

Sudah ada dua terpidana dengan vonis hukuman kebiri, meraka adalah Pertama, Muhamad Aris yang diputus oleh PN Mojokerto dengan Nomor Perkara 69/Pid.Sus/2019/PN. Mjk dan dikuatkan oleh putusan Pengadilan Tinggi Surabaya Nomor : 695/Pid.Sus/2019/PT SBY dengan putusan 12 tahun penjara denda 100 juta rupiah serta pidana tambahan berupa kebiri kimia. Kedua, Rahmat Santoso Slamet, alias memet divonis di Pengadilan Negeri Surabaya dengan denga isi putusan 12 tahun penjara dan denda 100 juta rupiah serta pidana tabahan berupa kebiri 
kimia selama 3 bulan. Secara teknis, belum ada aturan teknis mengenai kebiri kima bagi pelaku kejahatan seksual, bentuk aturan tersebut adalah Peraturan Pemerintah (PP) masih dirancang oleh pemerinatah Indonesia.

Selain itu, jika melihat Tindakan kebiri perspektif hukum islam sebenarnya hukum islam tidak secara tegas mengatur tentang hukuman tindakan kebiri bagi pelaku kejahatan seksual terhadap anak di bawah umur, namun tidak berarti islam tidak membicarakan mengenai kebiri. Ada beberapa hadis yang memicarakan larangan kebiri namun secara konteks berbeda, sebab dalam hadist itu kebiri bukan sebagai hukuman namun lebih kepada menahan hasrat seksual agar tidak terjadi perjinahan ketika para sahabat mengikuti perang Bersama nabi Muhammad saw. Akan tetapi bukan berarti tindakan kebiri kebiri sebagai suatu hukuman tidak bisa hukumi, Hukuman kebiri yang diatur dalam UU 17 tahun 2016 merupakan hukuman yang dikatagorikan sebagai hukuman takzir, sebab sibuat oleh negara atau pemimpin untuk menangulangi kajahatan seksual terhadap anak agar tidak terjadi kembali dan menimbulkan efek jera.

Beberapa penelitian sebelumnya yang mempunyai korelasi dengan penelitian penulis antara lain penelitin atas nama Messy Rachel dan Mariana Hutapea tentang Penerapan Hukuman Tindakan Kebiri Kimia Dalam Perspektif Ham berfokus pada penerapan tindakan kebiri yang bertentangan Ham dan penelitian atas nama Baharudin Zamawi tentang Aplikasi Teori Fungsi Interpretaso Jorge Je Gracia Tentang Hadist Kebiri. Penelitan keduanya hanya berfokus pada satu kajian saja, berbeda dengan penelitian penulis yang berfokus pada kedua kajian yakni kajian Hak Asasi manusia dan kajian Hukum Islam, sehingga dalam penelitian ini kita dapat mengetahui bagaimana hukuman kebiri perspektif Ham yang bukan hanya melihat dari proses pelaksanannya namun juga membahas paradigma pemidanaan yang harus berorientasi pada pemulihan korban serta adanya gantirugi terhadap korban itu sendiri dan dilihat juga dalam perspektif hukum islam bagaimana sebenarnya kebiri dalam padangan hukum islam terkhusus dalam hukum pidana islamnya.

Berdasarkan hal tersebut di atas, penulis tertarik untuk mengkaji dalam penelitian ini dengan memilih judul penelitian Pemidanaan Kebiri Terhadap Pelaku Kejahatan Seksual Kepada Anak Dalam Perspektif Hak Asasi Manusia Dan Hukum Islam.

Adapun identifikasi masalah pada penelitian ini berfokus terhadap dua masalah. Pertama bagaimana hukuman kebiri kebiri kimia yang 
dijatuhkan kepada Pelaku Kejahatan seksual ditinjau dari Hak Asasi manusia. Kedua, bagaimana hukuman kebiri bagi pelaku kejahatan seksual dalam perspektif hukum Islam.

\section{Metodologi}

Penelitian ini mengenai saksi kebiri yang diberikan kepada pelaku kejahatan seksual kepada anak perspektif Hak Asasi manusia dan Hukum Islam. Metode pendekatan yang digunakan adalah Yuridis Normatif dengan jenis data yaitu data primer dan sekunder. Data yang diperloleh dianalisa secara kuantitatif. Penelitian ini adalah penelitian hukum normative melalui kajian peraturan hukum atau bahan hukum yang ada. Penulis juga melakukan wawancara beberapa narasumber untuk menemukan dan memperdalam jawaban dari identifkasi masalah yang diteliti. Selain wawancara, peneliti juga melakukan penelitian kepustakaan berupa dokumen, buku dan bahan pustaka lainnya. Hasil pengumpulan data penulis analisis dengan teori-teori yang relevan dengan penelitian ini.

\section{Hukuman Kebiri Kebiri Kimia Perspektif Hak Asasi Manusia}

Indonesia sudah membuat kebijakan hukum pidana terhadap pelaku kejahatan seksual terhadap anak dengan menerapkan sanksi tindakan tambahan berupa kebiri kimia, hal tersebut jelas diatur dalam pasal 81 ayat (7) Undang-undang Nomor 17 tahun 2016 tentang penetapan Perpu No 1 Tahun 2016. Hukuman tindakan kebiri dilakukan kepada pelaku setelah menyelesaikan masa hukuman pidana penjara yang diputus majelis hakim di pengadilan. Jangka waktu tindakan kebiri maksial dua tahun dengan proses pengawasan yang ketat dari pihak yang berwenang dalam hal ini adalah jaksa.

Secara rinci kita bisa melihat bunyi pasal 81 yang mengatur tentang kebiri: Pertama, Setiap orang yang melanggar ketentuan sebagaimana dimaksud dalam Pasal 76D dipidana dengan Pidana penjara paling singkat 5 (lima) Tahun dan paling lama 15 (lima belas) Tahun dan denda paling banyak Rp. 5.000.000.000,00 (lima miliar rupiah); Kedua, Ketentuan Pidana sebagaimana dimaksud pada Ayat (1) berlaku pula bagi setiap orang yang dengan sengaja melakukan tipu muslihat, serangkaian kebohongan, atau membujuk anak melakukan persetubuhan dengannya atau dengan orang lain. 
Ketiga, Dalam hal tindak Pidana sebagaimana dimaksud pada Ayat (1) dilakukan oleh orang tua, wali, orang-orang yang mempunyai hubungan keluarga, pengasuh anak, pendidik, tenaga kependidkan, aparat yang menangani perlindungan anak, atau dilakukan oleh lebih daari satu orang secara bersama-sama, Pidananya ditambah $1 / 3$ (sepertiga) dari ancaman Pidana sebagaimana dimaksud pada Ayat (1); Keempat, Selain terhadap pelaku sebagaimana dimaksud pada Ayat (3), penambahan 1/3 (sepertiga) dari ancaman Pidana juga dikenakan kepada pelaku yang pernah dipidana karena melakukan tindak Pidana sebagaimana dimaksud dalam Pasal 76D.

Kelima, Dalam hal tindak Pidana sebagaimana dimaksud dalam Pasal 76D menumbulkan korban lebih dari 1 (satu) orang, mengakibatkan luka berat, gangguan jiwa, penyakit menular, terganggu atau hilangnya fungsi reproduksi, dan/atau korban meninggal dunia, pelaku dipidana mati, seumur hidup, atau Pidana penjara paling singkat 10 (sepuluh) Tahun dan paling lama 20 (duapuluh) Tahun; Keenam, Selain dikenai Pidana sebagaimana dimaksud pada Ayat (1), Ayat (3), Ayat (4), dan Ayat (5), pelaku dapat dikenai Pidana tambahan berupa pengumuman identitas pelaku.

Ketujuh, Terhadap pelaku sebagaimana dimaksud Ayat (4) dan Ayat (5) dapat dikenai tindakan berupa kebiri kimia dan pemasangan alat pendeteksi elektronik; Kedelapan, Tindakan sebagaimana dimaksud pada Ayat (7) diputuskan bersama-sama dengan Pidana pokok dengan memuat jangka waktu pelaksanaan tindakan; Kesembilan, Pidana tambahan dan tindakan dikecualikan bagi pelaku Anak.

Selain itu, diantara Pasal 81 dan Pasal 82 disisipkan 1 (satu) Pasal yakni Pasal 81A yang bebunyi sebagai berikut : 1) Tindakan sebagaimana dimaksud dalam Pasal 81 Ayat (7) dikenakan untuk jangka waktu paling lama 2 (dua) Tahun dan dilaksanakan setelah terpidana menjalani Pidana pokok; 2) Pelaksanaan tindakan sebagaimana dimaksud pada Ayat (1) di bawah pengawasan secara berkala oleh kementerian yang menyelenggarakan urusan pemerintahan di bidang hukum, sosial, dan kesehatan; 3) Pelaksanaan kebiri kimia disertai dengan rehabilitasi; 4) Ketentuan lebih lanjut mengenai tata cara pelaksanaan tindakan dan rehabilitasi diatur dengan Peraturan Pemerintah.

Beberapa negara telah memberlukan hukuman kebiri sebagai hukuman bagi pelaku kejahatan seksual diantaranya inggris, polandia, 
rusia, jerman, Republik Ceko, Denmark, swedia, spanyol, California, florida, geogria, lowa, lousiana, montana, Oregon, Texas, winconis, dan korea selatan ${ }^{2}$. Negara yang secara tegas mengatur kebiri kimia dalam bentuk suntikan kimia, salahsatunya adalah norwegia yang meberlakukan hukuman kebiri pada tahun 2010 bagi pelaku kejahatan seksual. ${ }^{3}$ Namun ada juga negara yang hanya menerapkan hukuman kebiri kimia bagi pedofilia.

Dibeberapa negara yang memberlakukan hukuman kebiri, kebiri kimia diterapkan untuk mengobati para pelaku kejahatan seksual itupun atas persetujuan dari pelakunya tersebut yang prosesnya juga melibatkan ahli medis, beberapa negara tersebut antara lain swedia, jerman, Denmark dan australia. ${ }^{4}$ Kebiri bisa dilakukan dengan dua acara yaitu Pertama, dengan melakukan bedah yakni mengangkat sebagian atau seluruhnya bagian organ kelamin. Kedua, dengan cara disuntik kimia dengan memasukan zat-zat kimia kedalam alat kelamin sehingga menghilangkan fungsi dari kemalinnya tersebut. ${ }^{5}$

Indonesia sendiri menerapkan hukuman kebiri kimia, kebijakan ini banyak terjadi prokontra, sebab hukuman kebiri ini dianggap bertentangan dengan konstitusi dan UU di Indonesia. Pasal 28 G ayat 2 UUD 1945 yang menyebutkan: "Setiap orang berhak untuk bebas dari penyiksaan yang merendahkan derajat martabat manusia dan berhak memperoleh suaka politik dari negara lain" Selain itu, dalam pasal 33 ayat 1 UU No. 39 tahun 1999 tentang Hak asasi Manusia menyebutkan: "Setiap orang berhak untuk bebas dari penyiksaa, penghukuman, atau perlakuan yang kejam, tidak manusiawi, merendahkan derajat dan martabat kemanusiaannya"

Hukuman kebiri juga dianggap bertentangan dengan pasal 7 UU Nomor 5 tahun 1998 tetang Ratifikasi konvensi yang menetang penyiksaan dan perlakuan atau hukuman lain yang kejam, tidak manusiawi, merendahkan derajat dan martabat kemanusiaanya yang menyebutkan:

2 Supriadi Dkk, Catatan Kritis Atas Kebijakan Kebiri Bagi Pelaku Kejahatan Seksual Anak DI Indonesia (Jakarta: Institute for Criminal Justice Reform, 2016).

3 Zachary Edmods, "Analiziing the Sex Disparity in Chemical Castration," Gender and Law Michigan Vol 19 (2012): 484.

4 Nuzul Quraini Mardiya, "Penerapan Hukuman Kebiri Kimia Bagi Pelaku Kekerasan Seksual," Jurnal Konstitusi 14, no. No. 1 (2017): 215-33.

5 Wahyu Agus Hartono and Puguh Dwi Hananto, "Perbandingan Hukum Pidana Kebiri Bagi Pelaku Tindak Kekerasan Seksual Terhadap Anak Di Beberapa Negara," Recidive 2, no. No. 3 (2013): 290-300. 
"Tidak ada seorangpun boleh dikenai penyiksaan, atau perlakuan atau hukuman yang keji, tidak manusiawi atau merendahkan martabatnya, khususnya tidak seorangpun tanpa persetujuannya secara sukarela dapat dijadikan eksperiman medis atau ilmiah"

Dengan demikian, secara konstitusional, rumusan yang mengatur tentang hak asasi manusia mengandung makna bahwa ketentuan itu dapat memberikan jaminan dan perlindungan hukum terhadap setiap warga negara untuk memperoleh kepastian hukum yang adil dalam sebuah proses peradilan pidana. Artinya, ketentuan tersebut mewajibkan siapapun termasuk negara untuk tidak memperlakukan orang secara tidak adil dan semena-mena dengan melanggar Ham. Berkaitan dengan proses hukum yang adil, kita mengenail asa due process of law sebagai manifestasi pengakuan Ham dalam proses peradilan pidana, asas tersebut harus kita junjung tinggi oleh semua pihak termasuk oleh Lembaga penegak hukum

Dari beberapa regulasi diatas, poin pentingnya adalah negara harus menjungjung tinggi hak orang untuk bebas dari hukuman yang tidak manusiawi dan merendahkan derajat dan martabat kemanusiaan. Walaupun tujuan dari hukuman ini salah satunya adalah memberikan efek jera, namun hal tersebut belum bisa dibenarkan, faktanya angka kejahatan seksual terhadap anak cenderung meningkat. Hukuman kebiri jelas merupakan hukuman yang tidak manusiawi dan merendahkan martabat kemanuasiaan, sebab hukuman kebiri hanya berorientasi pada pembalasan atas tindakannya serta penyiksaaan bagi pelakunya.

Kebiri kimia merupakan Pemberian zat antiandrogen kepada diri pelaku yang melakukan pelecehan seksual untuk menurunkan/ menghilangkan hasrat seksual dan libido, Menurut Ikatan Dokter Indonesia walapun kebiri tersebut bisa menurunkan hormone testoteron namun efek samping lain dari hukuaman kebiri kimia akan membuat para pelaku tersebut mengurangi kepadatan tulang, penuaan dini, resiko penyakit jantung, hilang kepercayaan diri, lebih agresif dan emosional sehingga hukuman kebiri tidak bisa jadi jaminan untuk tidak terulang kembalinya perbuatan tersebut, dan dikhawatirkan ada masalah baru. Oleh karenanya hukuman kebiri adalah hukuman yang mengandung unsur penyiksaan bertentangan dengan UU 39 tahun 1999 tentang Hak Asasi Manusia yang menyebutkan penyiksaan adalah setiap perbuatan yang dilakukan dengan sengaja, sehingga menimbulkan rasa sakit atau penderitaan yang hebat baik jasmani maupun rohani. 
Hukuman kebiri harusnya tidak menjadi bagian hukum Indonesia yang orientasi hukumnya tidak lagi menggunakan paradigma pembalasan seperti jaman kolonial, Indonesia sendiri dalam hal pemidanaan sudah beralih menggunakan paradigma pemsayarakatan, yang tujuannya dapat memperbaiki prilaku pelaku dan bisa kembali diterima masyarakat setelah menjalani masa hukuman, yang paling penting dalam kasus pelecehan seksual terutama kepada anak, bagaimana negara dan masyarakat lebih memperhatikan kepentingan korban yang secara fisik dan psikis terganggu untuk dilakukan pendampingan yang intensif kepada anak yang menjadi korban pelecehan seksual tersebut agar bisa kembali pulih.

Menurut peneliti, melakukan pemulihan atau rehabilitasi terhadap fisik dan mental korban kejahatan seksual dalam hal ini anak jauh lebih relevan sesuai tujuan hukum pidana yakni memberikan kedilan bagi korban dari pada kita harus menerapkan hukuman kebiri yang belum jelas efektifitasnya dan tentunya melanggar Hak Asasi manusia. Hal tersebut tentu sesuai dengan tujuan perlindungan anak yakni kepentingan pemulihan/rehabilitasi korban anak jauh lebih penting agar menghilangkan rasa trauma yang berkepanjangan. Oleh karenanya Negara harus memampu memfasilitasi korban tindak pidana seksual untuk bisa pulih dari rasa trauma baik dalam bentuk program kebijakan maupun Lembaga khusus yang fokus melakukan rehabilitasi bagi korban itu sendiri. Sehingga pemidanaan itu bukan hanya diartikan melakukan penindakan terhadap pelaku tetapi juga bagaimana ada penanganan terhadap korban.

Dalam perspektif hak asasi manusia, tujuan pemidanaan harus berorientasi, pertama membuat pelaku bertanggung jawab atas kesalahan yang diperbuat, kedua membuat pelaku tindak pidana tidak mengulangi tindak pidana yang sama atau tidak pidana yang lain dikemudian hari, ketiga membuat pelaku tindak pidana menjadi orang yang dapat hidup kembali sebagai warga masyarakat yang menjungjung tinggi hukum dan Ham orang lain, keempat membuat orang lain gentar melakukan tindak pidana. Pemidanaan di Indonesia sudah saaatnya diarahkan kepada pemidanaan yang tidak hanya sekedar memberikan efek jera dan memberikan rasa penderitaan bagi terpidana namun juga harus berorientasi pada kepentingan korban. Konsep Pemidanaan dengan perspektif Hak Asasi Manusia dapat dilakukan dengan pendekatan keadilan restorative, dimana pidana bisa bersifat altenatif jalan terakhir yang lebih diutamakan 
adalah perbaikan pemulihan posisi korban yang menjadi korban dengan konsep rehabilitasi maupun dengan proses ganti rugi kepada korban (restitusi) seperti diatur dalam pasal 7 undang-undang No. 13 tahun 2006 tentang perlindungan saksi dan korban.

Hak asasi manusia mempunyai hal yang fundamental, yakni kehidupan dan martabat manusia. Martabat manusia pasti akan terganggu ketika menjadi korban penyiksaan walapun dalam hal ini sebagai pelaku kejahatan, tetap saja haknya harus terlindungi. UU No. 8 tahun 1981 tengang Hukum Acara Pidana melatakan pelaku kejahatan sebagai manusia yang bermartabat sehingga dalam proses penegakan hukum hak tersangka harus dipenuhi. Namun dengan adanya hukuman kebiri ini seolah-olah apa yang sudah perjuangkan untuk hak asasi manusia kembali lagi memposisikan terdakwa untuk dibalas prilakunya, bukan untuk dibina sehingga menjadi manusia yang baik.

Menurut Manfred Nowak ${ }^{6}$ terdapat empat prinsip yang paling fundamental dalam HAM antara lain prinsip universal, prinsip tidak terbagi, prinsip saling bergantung dan prinsip saling terkait. Selain itu Rhona K.M Smit menambahkan prinsip Ham yang lain yaitu prinsip kesetaraan dan non diskriminasi. Indonesia sendiri menekankan satu prinsip yang sama penting yakni tanggung jawab negara. Negara wajib bertanggung jawab atas tegaknya serta pelaksanaan ham di indoneisa kepada siapapun tanpa memandang kasta.

Proses perlindungan hak asasi manusia salahsatunya dapat dilaksanakan dalam system pemidanaan Indonesia. Bicara mengenai pemidanaan, maka Prof. Sudarto mengatakan bahwa:

"Perkataan pemidanaan sinonim dengan istilah penghukuman. Penghukuman sendiri berasal dari kata hokum, sehingga dapat diartikan sebagai menetapkan hokum atau memutuskan tentang hukumannya (berechen). Menetapkan hokum ini sangat luas artinya, tidak hanya dalam lapangan hokum pidana saja tetapi juga bidang hokum lainnya. Oleh karena istilah tersebut harus disempitkan artinya, yakni penghukuman dalam perkara pidana yang kerapkali sinonim dengan pemidanaan atau pemberian atau penjatuhan pidana oleh hakim"7

6 Eko Riyadi, Hukum Ham Perspektif Internasional, Regional Dan Nasional (Jakarta: Rajawali, 2018).

${ }^{7}$ Lamintang, Hukum Pidana (Bandung: Binacipta, 2015). 
Oleh karena itu, perlu proses penegakan hokum secara secara adil agar melindungi hak asasi manusia termasuk memberi hukuman yang tidak melanggar hak manusia. Untuk mencapai tujuan penegakan hukum diarahkan untuk mencapai sesuai tujuan hukum dan tentunya tujuan masayarakat dengan proses penegakanhukum oleh pihak yang mempunyai wewenang, dan bertanggung jawab atas penegakan hukumnya itu sendiri baik dibidang hukum publik atau privat. ${ }^{8}$

Kebijakan hukuman kebiri dapat diktagorikan sebagai hukuman yang melanggar Ham, oleh karenanya kebijakan hukuman ini banyak ditolak oleh organisasi kedokteran yang diminta untuk menjadi eksekutor kebiri ini. Selain itu, termasuk beberapa organisasi Ham juga menolak hukuamn kebiri dengan alasan yakni bahwa pertama hukuman kebiri tidak dibenarkan dalam sisitem hukum pidana Indonesia, kedua hukuman kebiri tentunya melanggar Ham yang jelas bertentangan dengan konvensi internesional yang sudah diratifikasi oleh Indonesia antara lain konvensi hak sipil dan politik dan kenvensi anti penyiksaan. ${ }^{9}$

Penghapusan kebijakan kebiri adalah upaya penegakan terhadap hak asasi manusia dalam system pemidanaan Indonesia. Bukan berarti dengan dihapuskan hukuman kebiri, kita membiarkan prilaku para pelaku kejahatan seksual tidak di kenai sanksi dan berkeliaran di tengah masyarakat. Pemidanaan terhadap para pelaku kejahatan seksual harus kita lakukan dengan mengoptimalkan pidana pokok yang sudah diatur dalam Undang-udang perlindungan anak sebelumnya berupa penjara, denda dan pengumuman identitas korban, selain itu mendorong upaya ganti rugi kepada korban oleh pelaku.

\section{Pandangan Hukum Islam tentang hukuman kebiri untuk pelaku kejahatan seksual}

Islam tidak secara tegas mengatur tentang hukuman tindakan kebiri bagi pelaku kejahatan seksual terhadap anak di bawah umur, namun tidak berarti islam tidak membicarakan mengenai kebiri. Pengaturan kebiri bisa kita lihat dalam hadist yang tidak mebolehkan para

8 Basrief. Arief, "Dimensi Keadilan Dan Kepastian Hukum Kaitannya Dengan Pembentukan Opini Publik Dalam Proses Penegakan Hukum Indonesia," Institute For Legal \& Constitutional Govarnmentm Jurnal, No. I (2010): hlm. 59.

${ }_{9}$ Messy Rachel and Mariana Hutapea, "Penerapan Hukuman Tindakan Kebiri Kimia Dalam Perspektif Ham," Jurnal Hukum Magnum Opus 3, no. No. 1 (n.d.): 30. 
sahabat untuk melakukan kebiri pada saat ikut berperang dengan nabi, berikut hadist nabi yang melarang tindakan kebiri:

"Rasulullah SAW telah menolak Utsman bin Mazh"un RA untuk melakukan tabattul (meninggalkan kenikmatan duniawi demi ibadah semata). Kalau sekiranya Rasulullah SAW mengizinkan Utsman bin Mazh"un untuk melakukan tabattul, niscaya kami sudah melakukan pengebirian." (HR Bukhari no 5073; Muslim no 3390). ${ }^{10}$

Selain itu hadist lain yang melarang kebiri adalah:

"Dahulu kami pernah berperang bersama Nabi SAW sedang kami tidak bersama isteri-isteri.Lalu kami berkata (kepada Nabi SAW),"Bolehkah kami melakukan pengebirian?"Maka Nabi SAW melarang yang demikian itu."(HR Bukhari no 4615; Muslim no 1404; Ahmad no 3650; Ibnu Hibban no 4141). 11

Hadist diatas merupakan sebuah larangan dari nabi kepada sahabat agar tidak melakukan kebiri, tetapi hal tersebut bukanlah sebuah bentuk hukuman dalam islam yang secara spesifik untuk pelaku kejahatan seksual. Proses menentukan sebuah hukum, islam mempunyai metodologi tersendiri apakah peristiwa tersebut dapat di hukumi atau tidak, metodologinya adalah dengan melakukan ijtihad, dimana ijitihad tersebut haruslah jelas sandaran hukumnya apakah dia ada nash yang mengatur secara tegas atau tidak, jika peristiwa tersebut merupakan peristiwa yang baru terjadi maka dalam ijtihad tersebut harus di hukumi dengan melihat hukum asalnya.

Hukum asal pelecehan seksual atau pemerkosaan terhadap anak adalah perjinahan dan homoseksual. Islam telah mengatur secara tegas hukuman perjinahan yakni hukuman cambuk selama 100 kali atau rajam (binuh) sedangkan hukuman bagi pelaku homoseksual ia dihukum mati, namun jika hanya sebatas pelecehan saja tidak sampai melakukan jinah atau homo seksual hukumannya tazir atau hukuman yang ditentukan oleh negara. Dari penjelasan diatas kita bisa simpulkan bahwa hukuman kebiri tidaklah dikenal oleh islam itu sendiri, dan islam melarang tindakan kebiri.

10 Imam Muslim, Kitab Shahih Muslim (Bandung: Cv Penerbit Diponegoro, 2016).

${ }_{11}$ Ibnu Hajar Asqalani, Fath Al Bari Fi Syarh Shahih Al Bukhari Jakarta: Pustaka Azzam, 2001). 
Dalam penelitian yang dilakukan oleh Bahruddin Zamawi mengenai kebiri dengan menggunakan pendekatan teori fungsi interpretasi gracia, menurutnya teori ini memiliki tiga unsur untuk menganalisis kehidupan. Hasil analisis berkaitan dengan hadist mengenai kebiri yang menjadi hukuman tambahan yang diterapkan oleh pemerintah Indonesia bagi pelaku kejahatan seksual terhadap anak. Larangan mengenai pengebirian yang disebutan dalam hadist nabi Muhammad Saw menurutnya terdapat beberapa alasan yakni, Pertama pengebirian yang dilakukan oleh para sahabat adalah dalam rangka ibadah, namun tidak dibenarkan jika perbuatannya berlebihan apalagi sampai dikebiri. Kedua, walapun kebiri tersebut dilakukan dengan niat terhindar dari perzinahan, namun kebiri bukanlah cara yang bisa dilakukan, lebih baik dengan melakukan sholat dan puasa untu menahan hawa nafsu. Ketiga, bagi orang yang sudah melaksanakan sholat dan puasan tidak mampu menahan hasrat seksual untuk menghindari perzinahan maka tindakan kebiri diperbolehkan jika memang diinginkan (darurat) namun harus tetap hati-hati dalam pelaksanaannya sebab efek dari kebiri itu sangat besar dan berdampak buruk bagi pelakunya. ${ }^{12}$

Hukuman kebiri merupakan hukuman yang dikatagorikan sebagai hukuman takzir, sebab dibuat oleh negara atau pemimpin untuk menangulangi kajahatan seksual terhadap anak. Hukuman takzir itu diartikan sebagai hukuman yang dikenakan kepada pelaku tindak kejahatan yang tidak dikenai hukuman Qishas-Diat dan tidak pula hukuman hudud ${ }^{13}$. Ukuran Hukuman takzir tidak ditentukan oleh nas, sebab hukuman takzir besar dan kecilnya ditentukan oleh hakim yang memutuskan sebuah perkara atau permasalahan hukum ${ }^{14}$. Sehingga kita bisa artikan bahwa hukuman Takzir merupakan hukuman yang tidak datur dalam nas baik alqur'an maupun hadist, sanksinya diserahkan kepada penguasa/negara dimana sanksinya sesuai perbuatan yang dilakukan untuk mengurangi kejahatan dalam suatu negara.

12 Baharudin Zamawi, “Aplikasi Teori Fungsi Interpretaso Jorge Je Gracia Tentang Hadist Kebiri," Arief, Basrief. "Dimensi Keadilan Dan Kepastian Hukum Kaitannya Dengan Pembentukan Opini Publik Dalam Proses Penegakan Hukum Indonesia." Institute For Legal \& Constitutional Govarnment Jurnal. Edisi I, 2010: 59. Asqalani, Ibnu Hajar. Fath Al Bari Fi Syarh 2, no. No. 2 (2016): 401-25.

${ }^{13}$ Amir Syarifudin, Garis-Garis Besar Fiqih (Jakarta: Prenada, 2015).

${ }^{14}$ Halil Husairi. Darsi, "Takzir Dalam Perspektif Fikih Jinayat," Al-Qisthu Jurnal Kajian Ilmu-Ilmu Hukum 16, no. 2 (2019): 60-64. 
Hukuman kebiri yang diatur dalam Undang-undang No. 17 tahun 2016 tentang perlindungan anak menurut hukum islam dikatagorikan sebagai hukuman Takzir, yang mana aturan ini dibuat oleh pemerintah untuk menekan angka kejahatan sesuai prinsip keadilan kepastian dan kemanfaatan hukum. Kebutuhan atas dikeluarkannya kebijakan ini tergantung pemerintah yang berkuasa atas analisa serta melihat kepentingan hukum masyarakat. Peningkatan angka kejahatan seksual kepada anak membuat pemerintah membuat kebijakan untuk melakukan kebiri tehadap pelaku kejahatan seksual dengan tujuan agar adanya efek jera serta pembelajaran bagi para pelaku kejahatan seksual. Dalam hukum islam sendiri hukuman kebiri tidak dikenal, namun bukan berarti tidak dibolehkan. Oleh karena hukuman kebiri tidak diatur dalam nas, maka hukum kebiri dalam hukum pidana islam diklasifikasikan dalam hukuman Takzir yang ketentuannya diserahkan sepenuhnya kepada pemerintah itu sendiri asalkan sesuai prinsip dan nilai keadilan dalam masyarakat. Bentuk hukuman takzir dalam hukum pidana islam tidak diatur secara tegas apa hukumannya, oleh karenanya kebiri dapat menjadi salah satu bentuk hukuman takzir sebagai hukuman bagi pelaku kejahata seksual.

\section{Penutup}

Dari hasil pembahasan yang dilakukan penulis diatas dapat disimpulkan sebagai berikut: Pertama, Pelaksanaan hukum kebiri merupakan hukuman yang bertentangan dengan Hak Asasi Manusia yang telah di atur dalam Konsitutusi dan peraturan Perundang-undangan di Indonesia. Kedua, Hukum islam tidak mengatur secara tegas Mengenai hukuman kebiri, dalam beberapa hadist kebiri adalah tindakan yang dilarang oleh Nabi Muhammad Saw. Hukuman kebiri yang diatur dalam UU 17 tahun 2016 merupakan hukuman yang dikatagorikan sebagai hukuman takzir, sebab sibuat oleh negara atau pemimpin untuk menangulangi kajahatan seksual terhadap anak.

\section{Saran}

Saran penulis dari hasil penelitian ini adalah : Merekomendasikan kepada pemerintah pemerintah untuk mengevaluasi kebijakan hukuman kebiri ini agar di hapuskan dalam sistem pemidanaan Indonesia, oleh karena belum terbukti sebagai hukuman yang akan membuat efek jera terhadap masyarakat. Merekomendasikan kepada pemerintah untuk 
lebih fokus melakukan penanganan terhadap korban tindak pidana seksual kepada anak sampai tuntas.

\section{Daftar Pustaka}

Arief, Basrief. "Dimensi Keadilan Dan Kepastian Hukum Kaitannya Dengan Pembentukan Opini Publik Dalam Proses Penegakan Hukum Indonesia." Institute For Legal \& Constitutional Govarnmentm Jurnal, no. I (2010): 59.

Asqalani, Ibnu Hajar. Fath Al Bari Fi Syarh Shahih Al Bukhari. Jakarta: Pustaka Azzam, 2001.

Darsi, Halil Husairi. "Takzir Dalam Perspektif Fikih Jinayat." Al-Qisthu Jurnal Kajian Ilmu-Ilmu Hukum 16, no. 2 (2019): 60-64.

Edmods, Zachary. "Analiziing the Sex Disparity in Chemical Castration." Gender and Law Michigan Vol 19 (2012): 484.

Hartono, Wahyu Agus, and Puguh Dwi Hananto. "Perbandingan Hukum Pidana Kebiri Bagi Pelaku Tindak Kekerasan Seksual Terhadap Anak Di Beberapa Negara." Recidive 2, no. No. 3 (2013): 290-300.

Hasanah, Nur Hafizal, and Eko Suponyono. "Kebijakan Hukum Pidana Sanksi Kebiri Kimia Dalam Perspektif HAM Dan Hukum Pidana." Jurnal Megister Hukum Udayana 7, no. 3 (2018): 305-17.

Lamintang. Hukum Pidana. Bandung: Binacipta, 2015.

Mardiya, Nuzul Quraini. "Penerapan Hukuman Kebiri Kimia Bagi Pelaku Kekerasan Seksual." Jurnal Konstitusi 14, no. No. 1 (2017): 215-33.

Muslim, Imam. Kitab Shahih Muslim. Bandung: Cv Penerbit Diponegoro, 2016.

Rachel, Messy, and Mariana Hutapea. "Penerapan Hukuman Tindakan Kebiri Kimia Dalam Perspektif Ham." Jurnal Hukum Magnum Opus 3, no. No. 1 (n.d.): 30.

Riyadi, Eko. Hukum Ham Perspektif Internasional, Regional Dan Nasional. Jakarta: Rajawali, 2018.

Supriadi, Dkk,. Catatan Kritis Atas Kebijakan Kebiri Bagi Pelaku Kejahatan Seksual Anak DI Indonesia. Jakarta: Institute for Criminal 
Justice Reform, 2016.

Syarifudin, Amir. Garis-Garis Besar Fiqih. Jakarta: Prenada, 2015.

Zamawi, Baharudin. "Aplikasi Teori Fungsi Interpretaso Jorge Je Gracia Tentang Hadist Kebiri." Arief, Basrief. "Dimensi Keadilan Dan Kepastian Hukum Kaitannya Dengan Pembentukan Opini Publik Dalam Proses Penegakan Hukum Indonesia." Institute For Legal \& Constitutional Govarnment Jurnal. Edisi I, 2010: 59. Asqalani, Ibnu Hajar. Fath Al Bari Fi Syarh 2, no. No. 2 (2016): 401-25. 
208 | Adliya: Jurnal Hukum dan Kemanusiaan, Vol. 14, No. 2, Desember 2020

[Halaman ini sengaja dikosongkan] 